

\title{
Faces da modernidade: a experiência do Ciclo Suburbano Clube (Madureira/Rio de Janeiro - décadas de 1920-1960)
}

- Victor Andrade de Melo

Doutor em Educação Física pela Universidade Gama Filho (UGF).

Professor da Universidade Federal do Rio de Janeiro (UFR).

Rio de Janeiro, RJ - BRASIL

lattes.cnpq.br/9730234823420258

victor.a.melo@uol.com.br

(D) orcid.org/0000-0002-1983-1475

- Nei Jorge dos Santos Junior

Doutor em Lazer pela Universidade Federal de Minas Gerais (UFMG).

Professor da Faculdade União Araruama de Ensino (UNILAGOS).

Araruama, RJ - BRASIL

lattes.cnpq.br/5376923296880291

edfnei@hotmail.com

(D) orcid.org/5376923296880291

Para citar este artigo:

MELO, Victor Andrade de; SANTOS JUNIOR, Nei Jorge. Faces da modernidade: a experiência do Ciclo Suburbano Clube (Madureira/Rio de Janeiro - décadas

de 1920-1960). Tempo e Argumento, Florianópolis, v. 12, n. 30, e0202, maio/ago. 2020

dof http://dx.doi.org/10.5965/2175180312302020e0202 


\title{
Faces da modernidade: a experiência do Ciclo Suburbano Clube (Madureira/Rio de Janeiro - décadas de 1920-1960)
}

\begin{abstract}
Resumo
Em seus mais de 40 anos de trajetória (1926-1968?), o Ciclo Suburbano Clube tornou-se uma referência no bairro de Madureira e na cidade do Rio de Janeiro. Tendo em conta que foi uma expressão de movimentos de adesão a parâmetros de modernidade e de busca de valorização do subúrbio, este estudo tem por objetivo discutir a experiência dessa agremiação de ciclismo. O que interessa abordar é a particularidade da iniciativa, bem como sua relação com a construção de representações positivas sobre a região. Qual o perfil dos envolvidos? Como se relacionaram com outros grupos sociais? Que ações foram implementadas para materializar suas intenções? Como fontes, foram utilizados jornais e revistas publicados na capital nacional. Esperamos lançar um olhar diferenciado sobre a história do bairro, dos subúrbios e do Rio de Janeiro, tentando perceber como agentes diversos interferiram na produção do espaço, isso é, atuaram na conformação de uma identidade local.
\end{abstract}

Palavras-chave: Rio de Janeiro (RJ) - História. Esportes - História. Subúrbios. Madureira (Rio de Janeiro, RJ). Ciclismo.

\section{Faces of the modernity: the experience of the Ciclo Suburbano Clube (Madureira/Rio de Janeiro - 1920s-1960s)}

\begin{abstract}
In its more than 40 years of history (1926-1968?), the Ciclo Suburbano Clube has become a reference in the neighborhood of Madureira and in the city of Rio de Janeiro. Considering that it was an expression of movements of adherence to parameters of modernity and the search for valuing the suburb, this study aims to discuss the experience of this cycling association. What is important to address is the particularity of the initiative, as well as its relationship with the construction of positive representations about the region. What is the profile of those involved? How did they relate to other social groups? What actions have been taken to materialize their intentions? As sources, newspapers and magazines published in the national capital were used. We hope to take a different look at the history of the neighborhood, the suburbs and the Rio de Janeiro, trying to understand how different groups interfered in the production of the space, that is, acted in shaping a local identity.
\end{abstract}

Keywords: Rio de Janeiro (RJ) - History. Sports - History Subúrb. Madureira (Rio de Janeiro, RJ). Cycling. 
Faces da modernidade: a experiência do Ciclo Suburbano Clube (Madureira/Rio de Janeiro - décadas de 1920-1960)

Victor Andrade de Melo, Nei Jorge dos Santos Junior

Introdução

Os estudos sobre o modo de vida nas grandes cidades apontam para a existência de numerosas fronteiras culturais que muitas vezes podem se refletir na demarcação do mapa geográfico e social da cidade, por meio de processos históricos que infringem a uma dada localidade uma série de significações sociais.

Os subúrbios do Rio de Janeiro têm se destacado como um exemplo rico das relações entre espaço urbano e identidade social que se refletem no conjunto de estereótipos atribuídos a seus moradores, em geral por pessoas que não habitam essas regiões. (FERNANDEZ, 2005, p. 143)

Na esquina das ruas Capitão Macieira e Capitão Couto Menezes, bairro de Madureira/Rio de Janeiro, o casarão com aspecto bastante abandonado (figura 1), somente com muito esforço nos permitiria vislumbrar a intensa movimentação que outrora acolheu.

Figura 1: Antiga sede do Ciclo Suburbano Clube.
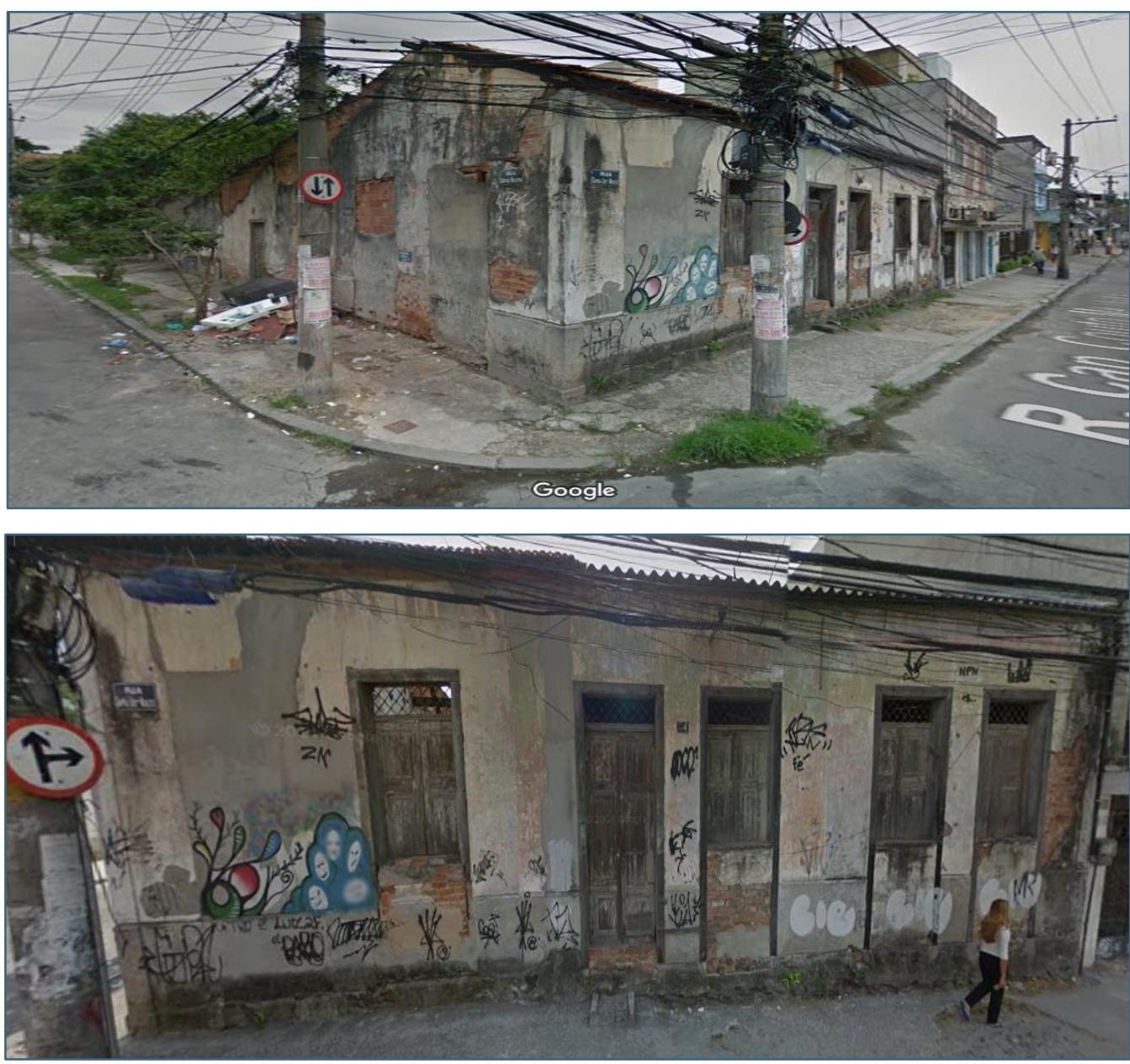

Fonte: Google Earth, c2020. 
Trata-se da última sede do Ciclo Suburbano Clube, tombada pelo órgão municipal de Patrimônio (RIO DE JANEIRO, 2004). A agremiação já chamou a atenção de Melo, Fonseca e Peres, que a citaram como exemplo de "o quanto uma parte da memória do esporte no Rio de Janeiro é, em larga medida, desconhecida", sendo uma "presença esquecida, resquícios que paradoxalmente expressam nossa facilidade de olvidar, indícios de uma temporalidade que hoje nos parece distante, ainda que suas marcas persistam no cotidiano" (MELO; FONSECA; PERES, 2017, p. 265).

Nos dias atuais, Madureira é um bairro da Zona Norte do Rio de Janeiro (figura 2). Segundo dados do Instituto Pereira Passos (2020), possui cerca de 50.000 habitantes, $1 / 5$ vivendo em nove favelas (dados de 2010). A taxa de analfabetismo é baixa (0,020). Quase todos os domicílios têm acesso à energia elétrica e saneamento. Possui 92\% de área urbanizada (dados de 2018), com uma economia basicamente movimentada pelos setores de prestação de serviços e comércio varejista. Dos 126 bairros da cidade, é o 67ㅇe em IDH (0,831, considerado alto). É uma localidade conhecida por uma série de referências culturais cuja história tem chamado a atenção de muitos pesquisadores.

Figura 2: Mapa da Cidade do Rio de Janeiro/Bairros. Madureira está destacado em vermelho.

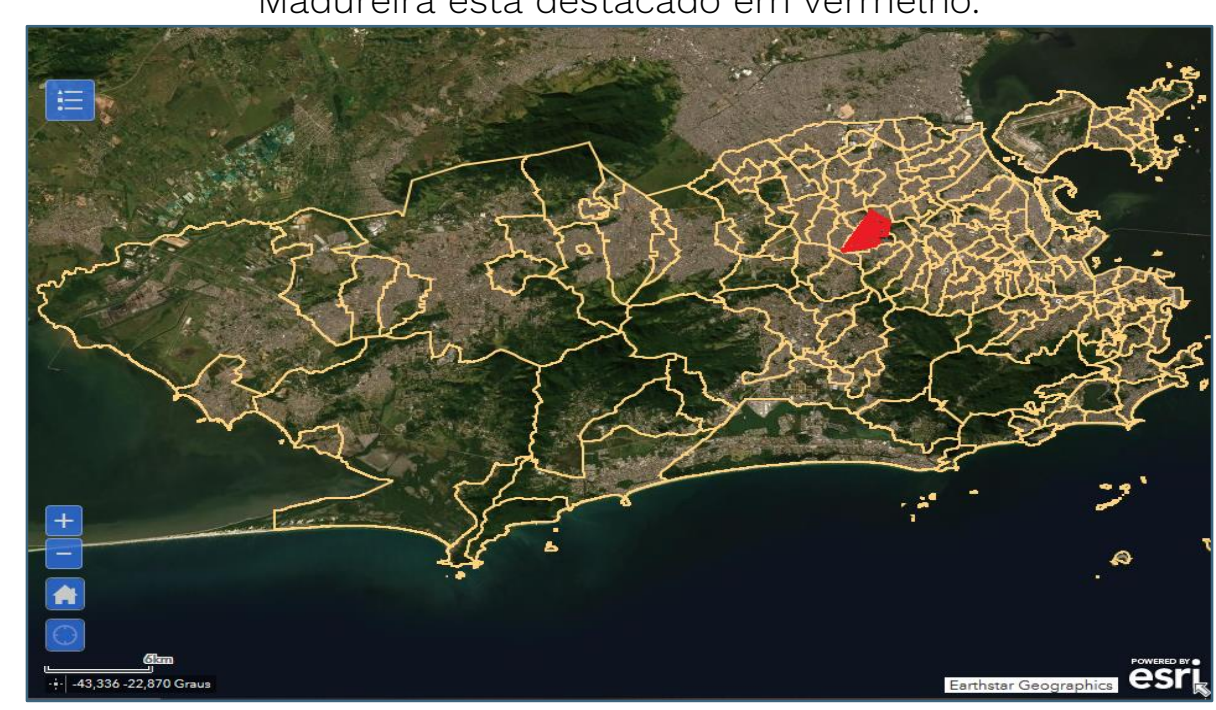

Fonte: Instituto Pereira Passos (2020).

Madureira é sede de duas das escolas de samba mais antigas e vitoriosas do Rio de Janeiro: Império Serrano e Portela. Mais antiga ainda é outra manifestação de matriz afro-brasileira que existe no bairro - o jongo da Serrinha. Seguindo essa tradição, tornou-se famoso o baile charme organizado no Viaduto Negrão de Lima. Essa conformação forjou uma certa identidade para o bairro, valorizada pelos grupos que lutam pelo reconhecimento de uma "cultura negra" de origem popular. 
Em linhas gerais, o desenvolvimento de Madureira não difere de outros bairros do subúrbio do Rio de Janeiro: antigas propriedades rurais foram dando lugar a loteamentos que se tornaram moradia de alguns dos que foram forçados a deixar a zona central da cidade em função das reformas urbanas, se instalando em localidades atendidas pela linha férrea ${ }^{2}$. Vale citar que a Serrinha, um dos mais célebres lugares da região,

teve origem num dos muitos loteamentos da Companhia de Colonização Agrícola, de propriedade do visconde Morais, que desde o princípio do século XX converteu em áreas urbanas imensas áreas do subúrbio carioca ocupadas por chácaras e fazendas. (FERNANDES, 2001, p. 59).

Merecem atenção, todavia, as peculiaridades do bairro que se localiza num entroncamento entre uma parte do subúrbio, a região metropolitana e a zona central do Rio de Janeiro, área na qual havia uma estreita planície. Desde o século XVII, Madureira se constituiu em lugar de passagem, trânsito e encontros (BRITO, 2016).

Martins (2009) informa que a região do Campinho, nas redondezas de Madureira, foi um ponto de cruzamento entre três zonas de grande importância para a economia do Rio de Janeiro: Irajá, Jacarepaguá e Santa Cruz. Com isso, tendo ali se constituído uma área de descanso e negócios, se desenvolveu uma ocupação relacionada à prestação de serviços. O autor sugere que, nesse momento, começou a se formar uma elite comercial que se tornaria uma das marcas do bairro. Essa tendência econômica se viu fortalecida pela principal atividade de Lourenço Madureira, que se tornou reconhecido atacadista depois de arrendar e se tornar proprietário de terras antes pertencentes à Fazenda de Campinho (MARTINS, 2009). Tal perfil se acentuou quando se inauguraram na região estações da Estrada de Ferro Pedro II: em 1858, Cascadura (importante entreposto que substituiu Campinho na centralidade das iniciativas comerciais), posteriormente Madureira (1890), Dona Clara (1897) e Magno (1898, essa

\footnotetext{
Sobre a ocupação dos subúrbios do Rio de Janeiro, ver: ABREU, Maurício. A evolução urbana do Rio de Janeiro. Rio de Janeiro: IPLANRIO, 1987; FERNANDES, Nelson da Nobrega. O rapto ideológico da categoria subúrbio. Rio de Janeiro: UFRJ, 1995 e OLIVEIRA, Márcio Piñon de Oliveira; FERNANDES, Nelson da Nóbrega (orgs.). 150 anos de subúrbio carioca. Rio de Janeiro: Lamparina, 2010
} 
pertencente à Estrada de Ferro Melhoramentos do Brasil) (BRITO, 2016; MARTINS, 2009).

Em função dessa conformação, cresceu o número de moradores no decorrer do século XIX, algo que se intensificou com a abolição da escravatura: muitos ex-escravos, da capital ou do interior, sem ter onde morar na zona central da cidade, se instalaram na região ${ }^{3}$. A centralidade de Madureira, todavia, somente se estabeleceu nas duas primeiras décadas do século XX em decorrência tanto da melhoria do transporte ferroviário (as novas estações acima citadas, maior frequência de trens, passagens mais baratas) (ABREU, 1987) quanto do estabelecimento de lavouras em terras da Light, companhia de eletricidade que ampliou sua oferta de serviços tendo em vista o crescimento dos subúrbios. Essa nova dinâmica da agricultura incentivou a criação de uma importante área de comércio, antecedente do atual Mercadão de Madureira (FERNANDES, 2001; BRITO, 2016).

Na verdade, o maior crescimento populacional se deu mesmo em função das reformas urbanas: se deslocou para a região tanto gente de estratos populares, sem opção de moradia no Centro da cidade, quanto grupos de estrato médio que procuravam aproveitar a oferta de habitações mais baratas, entre os quais profissionais ligados “à força e à segurança pública (Exército e Armada), ao funcionalismo público, ao setor de marítimos, à construção de aparelhos de transporte, mobiliário e cerâmica" (CRUZ, 2007, p. 76). A chegada de imigrantes (notadamente portugueses, mas também italianos e sírios, entre outros) para trabalhar na lavoura e no comércio tornou mais complexa a dinâmica social local. Na década de 1920, cerca de 30\% dos habitantes do Rio de Janeiro já viviam nos subúrbios (MIYASAKA, 2016); nos anos 1940, Madureira era o bairro mais populoso da zona (SILVA, 2003).

No decorrer desse processo, em meados do século XX, Madureira tornouse um dos bairros com maior movimentação comercial da cidade, atrás somente

\footnotetext{
Para mais informações, ver: RIBEIRO, Ana Paula Alves. Samba são pés que passam fecundando o chão... Madureira: sociabilidade e conflito em um subúrbio musical. Dissertação (Mestrado em Ciências Sociais) - Rio de Janeiro: UERJ, 2003.
} 
do Centro e Copacabana, um verdadeiro ponto fulcral entre as zonas do Rio de Janeiro, por alguns considerado a "Capital do Subúrbio" (FRAGA, SANTOS, 2015).

Perceba-se que na classificação de Abreu (1987), que divide o Rio de Janeiro em círculos, o bairro é exatamente o limite entre o segundo (da Tijuca até Madureira, no qual há alguma qualidade de urbanidade e serviços) ${ }^{4}$ e o terceiro (a Zona Oeste, caracterizada por maior precariedade). Desde os anos iniciais do século XX, com o crescimento e a diversificação populacional, em Madureira começaram a melhor se estruturar os divertimentos públicos. Vale ter em conta o que sugere Melo:

A estruturação de um mercado de entretenimentos, em geral, se
relaciona a algumas importantes mudanças na dinâmica das
cidades: uma maior disposição para a ocupação da cena pública
(decorrente de certa efervescência política, mas também da
circulação de novas ideias sobre a vida em sociedade), bem como
uma vitalidade econômica que tem como uma das marcas a
conformação de estratos médios que ampliam a base de
consumo. (MELO, 2020, p. 1).

Se de início, a "diversão por ali não era cinema, teatro ou concertos" (FERNANDES, 2001, p. 60), mas sim manifestações festivas de uma cultura popular de matriz afro-brasileira (BRITO, 2016), algumas dessas que hoje integram o principal registro da notoriedade de Madureira, os grupos que chegaram trouxeram novidades ao bairro. Destacaram-se as iniciativas de uma elite comercial que logrou grande prestígio, inclusive por se tornar protagonista de várias ações que tinham em conta conformar e explicitar a prosperidade local (FRAGA, SANTOS, 2015).

Como sugere Abreu (1987, p. 81), já no fim da segunda década do século XX, havia em Madureira "animadíssimos cafés, confeitarias, lojas de moda, armarinhos, mercado, ostentando algum luxo em quatro ou cinco lojas principais". Essas iniciativas "modernas", relacionadas a discursos de civilização e progresso, em muitas ocasiões se chocaram com a dinâmica das práticas ditas tradicionais já estabelecidas no bairro. 
A região contava, desde o início do século, com um número significativo de botequins, tabernas e clubes dançantes. Esses espaços marcados pela presença de populares movimentavam as redes e relações locais. Aos olhos dos frequentadores, não significavam necessariamente desordem, mas representavam um incômodo para os setores de estrato médio que em Madureira se instalavam, tornando-se um problema no tocante às tentativas de normatizar aquela ambiência caracterizada pela heterogeneidade social (CRUZ, 2007).

Esses estranhamentos, que tinham como pano de fundo preconceitos de ordem racial e socioeconômica, estavam relacionados a diferentes discursos de valorização da região, entabulados por lideranças locais a fim de enfrentar uma representação negativa que se construiu acerca dos subúrbios do Rio de Janeiro, estigmas de que se tratava de uma zona menos civilizada ${ }^{5}$. Nem mesmo a heterogeneidade social era reconhecida, sendo nesses discursos a região tratada de forma monolítica.

Como sugerem Fraga e Santos (2015, p. 18): "Sob outra perspectiva, neste jogo de contrastes, também importava afirmar a existência de uma elite suburbana, frente aos grupos populares que conferiam uma imagem estigmatizante de pobreza e abandono ao subúrbio". Ao mesmo tempo, não se deve perder de vista que, no tocante à relação "entre os setores médios e populares no subúrbio", também se pode falar em "partilhamento de valores, símbolos, pertencimentos e identidades". (FRAGA; SANTOS, 2015, p. 20).

Assim sendo, pode-se perceber ao redor desses entretenimentos "modernos" uma dupla dimensão, para além da diversão em si: uma estratégia para mostrar aos de fora que os subúrbios também tinham condições de desenvolver práticas que indicassem a ideia de progresso e civilização; ao mesmo tempo, internamente, marcar as hierarquias, sendo, portanto, indícios dos relacionamentos e conflitos entre diferentes grupos sociais.

O esporte foi uma dessas práticas modernas que se estruturaram em Madureira nas primeiras décadas do século XX. Neste estudo, interessa-nos a

\footnotetext{
Sobre a construção de estigmas sobre os subúrbios, ver: FERNANDES, Nelson da Nobrega. O rapto ideológico da categoria subúrbio. Rio de Janeiro: UFRJ, 1995.
} 
atuação de uma agremiação. O objetivo é discutir a experiência do Ciclo Suburbano Clube, sociedade de ciclismo que, nos seus mais de 40 anos de trajetória (1926-1968?), logrou obter destaque não somente no bairro, como também na cidade.

Vale ter em conta que os clubes esportivos eram importantes espaços de socialização, de articulação de certos setores tendo em vista não somente se divertir, mas também materializar algumas intenções. Ao investigar tal tema, estamos incentivados pelo que sugerem Fraga e Santos

[...] considerando o fato de que os bairros eram os locais específicos em que a ação em prol dos subúrbios era realizada e que os mesmos eram também importantes demarcadores na configuração de redes de relações sociais, é pertinente caracterizar de que forma esta ação empreendedora distinguia e hierarquizava grupos e localidades. (FRAGA; SANTOS, 2015, p. 15).

Não estamos sugerindo que houve uma relação tradicional centro-periferia na qual as lideranças de Madureira (subúrbio) teriam copiado exatamente o que se passava no Centro e Zona Sul. Certamente, nessas experiências estavam inspirados, e por muitas vezes as tentaram emular. Todavia, há que se perceber as marcas do lugar, tanto aquelas que são frutos das decisões dos envolvidos quanto as decorrências das especificidades de contexto, ambas manifestas no cotidiano da agremiaçãó ${ }^{\text {. }}$

O que nos interessa discutir é a particularidade da iniciativa bem como sua relação com a construção de representações positivas sobre o bairro. Algumas questões parecem pertinentes. Qual o perfil dos envolvidos? Como se relacionaram com outros grupos sociais? Que ações foram implementadas para materializar suas intenções? Para alcance do objetivo, como fontes, foram

\footnotetext{
Estamos fazendo uma analogia da ideia de trânsitos culturais entre os países centrais e periféricos. Consideramos trânsito cultural como um processo ativo de releitura, adaptação, apropriação, que acaba por gerar apreensões peculiares. Para um debate sobre o tema, ver: CANCLINI, Néstor García. Culturas híbridas: estratégias para entrar e sair da modernidade. São Paulo: Edusp, 1997 e MAIA, João Marcelo E. Costa Pinto em dois tempos: os efeitos periféricos na circulação de ideias. Tempo Social, São Paulo, v. 31, n. 2, p. 173-198, 2019. No sentido mais direto do termo periferia, estamos de acordo com os que defendem não ser adequado para dar conta da complexidade de formação dos subúrbios cariocas. Para uma abordagem do assunto, ver: GUIMARÃES, Roberta Sampaio; DAVIES, Frank Andrew. Alegorias e deslocamentos do "subúrbio carioca" nos estudos das Ciências Sociais (1970-2010). Sociologia \& Antropologia, Rio de Janeiro, v. 8, n. 2, p. 457-482, ago. 2018.
} 
Faces da modernidade: a experiência do Ciclo Suburbano Clube (Madureira/Rio de Janeiro - décadas de 1920-1960)

Victor Andrade de Melo, Nei Jorge dos Santos Junior

utilizados jornais e revistas publicados na cidade do Rio de Janeiro, consultados na Hemeroteca Digital da Biblioteca Nacional. Duas razões nos motivaram a tal escolha: a) discutir a repercussão pública das iniciativas, bem como os pontos de vista dos líderes do Ciclo Suburbano; b) são os únicos indícios que encontramos sobre a trajetória da agremiação, à exceção de algumas breves referências no Diário Oficial.

Para trato dos periódicos, tivemos em conta as sugestões de Luca (2005), sempre atentos à necessidade de prospectar a materialidade do investigado, notadamente quando se tratou de opiniões e posicionamentos ${ }^{7}$. Vale uma ressalva quanto ao uso de imagens. Boa parte é de caráter ilustrativo. Aquelas que foram diretamente utilizadas como fontes, mereceram uma observação mais detalhada no debate que segue ou antecede sua inserção no texto.

Neste estudo, partimos da ideia de que, sem negar a importância das manifestações culturais populares, é importante perceber que outros agentes interferiram na conformação de uma identidade para Madureirå ${ }^{8}$ atuaram na produção do espaço, fazendo uso da expressão de Henri Lefebrve:

Espaço (social) é um produto (social). Para entender esta tese fundamental, é necessário, antes de tudo, romper com a concepção generalizada de espaço, imaginado como uma realidade material independente, que existe em 'si mesma'. Contra tal visão, Lefebvre, utilizando-se do conceito de produção do espaço, propõe uma teoria que entende o espaço como fundamentalmente atado à realidade social - do que se conclui que o espaço 'em si mesmo' jamais pode servir como um ponto de partida epistemológico. O espaço não existe em 'si mesmo'. Ele é produzido. (SCHMID, 2012, p. 3)

\footnotetext{
Sobre as vantagens, Limites e cuidados a serem adotados ao utilizar esse recurso, ver: BRASIL, Eric; NASCIMENTO, Leonardo Fernandes. História digital: reflexões a partir da Hemeroteca Digital Brasileira e do uso de CAQDAS na reelaboração da pesquisa histórica. Estudos Históricos, Rio de Janeiro, v. 33, n. 69, p. 196-219, jan.-abr. 2020. Graças à Hemeroteca, foi possível trabalhar com todos os periódicos disponíveis na base. No caso deste estudo, esse procedimento foi importante por não haver tantas notícias sobre a agremiação investigada. O material consultado se mostrou pouco expressivo no que tange ao que desejamos discutir. Grande parte do publicado era a divulgação de resultados e atividades. Procuramos, ainda assim, prospectar tais indícios a partir das questões elencadas.

Identidade não é considerada como algo essencial, mas sim um conjunto de representações que se enfrentam na cena pública acerca das características de algo. Quando se consegue algum grau de consenso, ainda que não seguida por todos, se estabelece como uma estrutura estruturante, influenciando comportamentos e posicionamentos. Para um debate, ver: ANDERSON, Benedict. Comunidades imaginadas: reflexões sobre a origem e expansão do nacionalismo. Lisboa: Edições 70, 2005.
} 
A história de Madureira é marcada por aproximações e tensões entre o tradicional e o moderno, a começar pela importância do trem - símbolo de progresso - no seu desenvolvimento. Fernandes (2001) e Brito (2016) chamam atenção para tal aspecto ao discutir a obra "Carnaval em Madureira", de Tarsila do Amaral (1924), na qual inseriu uma representação da Torre Eiffel em meio a cenas típicas de uma festa popular. Na verdade, houve mesmo, no bairro, um coreto com esse formato, conseguindo a artista captar essa tendência local de, ainda que com conflitos, promover ajustes, encontros, trânsitos culturais ${ }^{9}$.

Nesse sentido, simbólica e materialmente, parece interessante discutir a trajetória de um clube de ciclismo, modalidade que tem como principal instrumento a bicicleta, uma máquina moderna que sempre foi encarada como sinal de progresso, mobilidade, velocidade e, até mesmo, liberdade. Essa faceta esportiva, que sempre conviveu com o uso da bicicleta nos âmbitos do lazer (passeios) e do trabalho, exponencia tais noções ${ }^{10}$. Dado o perfil do produto, não exatamente de alcance popular - vamos tratar desse tema no decorrer do texto -, a existência de uma agremiação dedicada à prática já é um indicador da heterogeneidade social do bairro.

Enfim, este estudo pretende fugir da ideia, por vezes monolítica, de que somente manifestações da cultura popular no subúrbio se desenvolveram. Na seara esportiva, essa tendência explica o interessa quase exclusivo pelo futebol. Há que se entender mais adequadamente a heterogeneidade dos grupos sociais que habitavam a região, bem como a diversidade de suas ações, descortinando iniciativas que ajudem a melhor perceber as tensões que se estabeleceram entre o centro e subúrbio na construção da urbanidade do Rio de Janeiro.

Trata-se de um problema atual, explícito em uma cidade muito marcada pelas desigualdades sociais, parte delas manifesta em sua divisão espacial. Os subúrbios continuam sendo vistos de forma estigmatizada, recebendo também

\footnotetext{
Sobre a importância dos coretos de Madureira, ver: FRAGA, Annelise Caetano; SANTOS, Miriam de Oliveira. Madureira, Capital dos Subúrbios (1940-1960): carnaval e comércio na produção de uma comunidade imaginada. Iluminuras, Porto Alegre, v. 16, n. 37, p. 11-31, jan./jun. 2015.

- Para mais informações, ver: WEBER, Eugen. França fin de siecle. São Paulo: Companhia das Letras, 1988 e SCHETINO, André Maia. Pedalando na modernidade: a bicicleta e o ciclismo no Rio de Janeiro e Paris na transição dos séculos XIX e XX. Rio de Janeiro: Apicuri, 2009.
} 
menor atenção do poder público. Por isso, muito nos estimulou a reflexão de Rangel e Rodrigues:

A qualidade específica da disciplina história é a de constituir compreensões acerca de passados, no entanto, o que temos percebido é que temos tido nas últimas décadas um interesse crescente por parte de historiadores e historiadoras em (também) pensar problemas próprios ao nosso presente, o que tem sido feito a partir de uma abertura temporal capaz de reconhecer passados que não passaram, irrupções e insurgências, bem como usos e apropriações do passado. (RANGEL; RODRIGUES, 2018, p. 4).

Esperamos, assim, lançar um olhar diferenciado sobre a história do bairro, dos subúrbios e do Rio de Janeiro, contribuir para uma visão mais múltipla da cidade, percebendo como grupos que, em certa medida, eram considerados subalternos foram agentes importantes na construção da trajetória da outrora capital nacional.

\section{5-1933 - Primeiros passos: um clube de distinção}

Antes do Ciclo Suburbano, houve outras iniciativas esportivas em Madureira. Provavelmente, a pioneira tenha sido o Clube Atlético de Irajá, criado em 1890, com sede no bairro, num momento em que a região já crescia, mas ainda era muito rural ${ }^{11}$. Nas redondezas, havia também o Clube Atlético Brasileiro, instalado em Cascadura. Para Melo, essas e outras agremiações de atletismo que surgiram nos subúrbios do Rio de Janeiro naquela ocasião tinham:

[...] relação com o avanço do processo de urbanização, a conformação de estratos médios e a melhoria dos transportes públicos - o aperfeiçoamento das linhas de bondes e instalação de ferrovias. Conforme a cidade se espraiava, os moradores dos novos bairros progressivamente se interessavam pelos esportes. Para essas novas zonas, longe do mar e por vezes também de hipódromos, os eventos dos clubes atléticos foram as primeiras experiências esportivas, as pioneiras nas quais se visualizou novos usos do corpo e uma mais distendida possibilidade de exposição pública. (MELO, 2020, p. 6)

\footnotetext{
1 Madureira, até 1926, fez parte do Distrito (antes da Freguesia) de Irajá. A partir de então, tornouse um Distrito separado.
} 
Outras agremiações que merecem referência são o Magno Futebol Clube (com sede na Rua Carolina Machado) e o Fidalgo Futebol Clube (com sede na Rua Domingos Lopes) - o primeiro fundado em 1913, o segundo em 1914 -, protagonistas da primeira rivalidade esportiva da região. Ambos lograram boa repercussão pública, conquistando, inclusive, títulos de algumas ligas do subúrbio (como da Associação Atlética Suburbana).

Em 1933, a partir de iniciativas de comerciantes locais, o Fidalgo deu origem ao Madureira Atlético Clube que, em 1971, se fundiu com o Madureira Tênis Clube (fundado em 1944) e o Imperial Basquete Clube (criado em 1935), gerando o atual Madureira Esporte Clube, presença constante nos campeonatos de futebol do Rio de Janeiro. Essas e outras iniciativas merecem ser mais profundamente investigadas $^{12}$, fugindo, contudo, do objetivo deste estudo. Ressaltamos, entretanto, três aspectos que serão úteis em nossa análise/interpretação: houve, na região de Madureira, muitas experiências agremiativas; as práticas esportivas foram comumente mobilizadas como forma de valorização do bairro; comerciantes e outras lideranças locais se envolveram na dinamização das sociedades.

Em outubro de 1925, uma nota na imprensa informou a criação de um “clube para desenvolver nos subúrbios, o agradável esporte do pedal" (CICLISMO, p. 8, 1925). Adotando o verde e branco como cores, com sede provisória na Rua Carolina Machado ${ }^{13}$, o Ciclo Suburbano Clube foi formado por jovens já envolvidos com o ciclismo em outras agremiações da cidade, membros de famílias conhecidas de Madureira, a maioria ligada ao comércio. O dia 1ํ de janeiro de 1926 foi estabelecido como data oficial de fundação (figura 3).

\footnotetext{
${ }^{12}$ Entre outros, podemos citar o importante Cascadura Futebol Clube, fundado em 1906, com sede no que hoje é a Avenida Dom Hélder Câmara, um dos pioneiros do subúrbio; o Pátria Sport Flumens, criado, no mesmo bairro, em 1917; o Esporte Clube Campinho, muito atuante na década de 1930; o Campinho Futebol Clube e o Independência Futebol Clube, dos anos 1910, com sede no Campinho. Além disso, havia o Fenianos e o Grupo Musical Lyra de Ouro, ambos ativos na década de 1920, em Cascadura; o Clube Carnavalesco Teimosos de Madureira (anos 1910). Caso curioso é o do Fidalgos de Madureira, criado em 1919, agremiação esportiva, mas também carnavalesca.

3 Trata-se de um longo logradouro, marcado pela existência de muitas casas comerciais e residenciais. Beirando a linha férrea, atravessa Cascadura, Madureira, Oswaldo Cruz, Bento Ribeiro e Marechal Hermes.
} 
Figura 3: Escudo do Ciclo Suburbano Clube

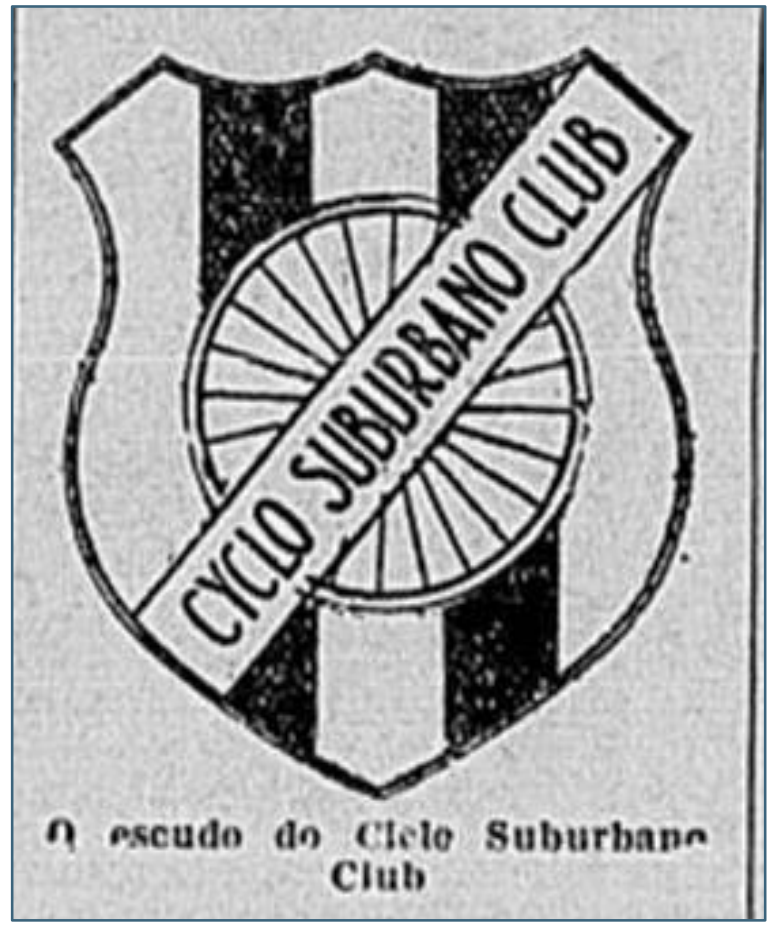

Fonte: Jornal do Brasil, p. 22, 1934a.

Arthur Ferreira, primeiro presidente, ciclista que competia sob o pseudônimo Ciclone, esportista envolvido com várias modalidades, era apresentado como alguém que gozava de "grande estima e prestígio no meio desportivo suburbano" (CICLO..., p. 4, 1926)14. Comerciante, atuava, como Manuel Coelho Mendes, outro fundador e importante associado do Ciclo Suburbano, no setor de venda, conserto e aluguel de bicicletas.

Em função de seu profundo envolvimento com a modalidade, Ferreira chegou a ser apresentado como "incontestavelmente o maior propulsor do ciclismo no Brasil" (VALIOSA..., p. 15, 1927). Na visão do presidente do Ciclo Suburbano, era um dos mais úteis esportes, uma ferramenta que contribuiria com o forjar da "raça" nacional, fortalecendo e educando a juventude (RÁPIDAS..., p. 4,1926$)$.

Seu discurso estava plenamente ajustado a uma compreensão corrente de que o esporte era mais do que uma diversão, era um instrumento educacional

\footnotetext{
Lançado em 1910, o jornal A Rua se propunha a estar sintonizado com os sentimentos populares, registrando tanto os clamores quanto os acontecimentos de forma generalizada. É possível que, por isso, tenha dado atenção aos subúrbios. Ver o editorial do primeiro número em: A RUA. A Rua, 21 abr. 1910, p. 5.
} 
que poderia contribuir com o progresso do país ${ }^{15}$. Os jovens precisavam ser disciplinados, a prática seria útil para tal, um olhar que certamente se afastava do estilo de vida dos que frequentavam as festas noturnas já usuais em Madureira.

Vale lembrar que nos Estatutos estava contemplada a ideia de que a finalidade principal do Ciclo Suburbano seria "proporcionar o desenvolvimento da educação física e moral da juventude brasileira, pela prática de competições desportivas, reuniões sociais e de fins culturais, sem prejuízo de outras atividades nobres que possa exercitar" (BRASIL, 1949, p. 3). Sempre houve um cargo de Diretor de Educação Física.

Tendo em conta esse perfil, quem poderia frequentar e ser aceito como associado ao Ciclo Suburbano? Não conseguimos muitos dados, mas identificamos que para se inscrever em algumas provas pagava-se 5\$000. Em 1927, quando o clube se estabeleceu em outra sede mais ampla, localizada na mesma Rua Carolina Machado, se informou que era esse também o valor da mensalidade (CICLISMO, p. 4, 1927). A título de comparação, tratava-se de metade do valor de um chapéu ou tênis, bens duradouros ${ }^{16}$. Vejamos também o que informa Malaia sobre as mensalidades de outras sociedades esportivas do subúrbio:

Analisando, por exemplo, as mensalidades e joias (um valor pago no ato da inscrição desses clubes) e, comparando-as com os maiores times da cidade, podemos ter uma proporção de como esses clubes abriam um espaço maior para as camadas mais baixas. São mensalidades, na grande maioria, de $1 \$ 000$ e joias de 3\$000. Em alguns casos, as mensalidades e as joias aumentam, mas raramente ultrapassam os $3 \$ 000$ réis. Pouco perto dos $10 \$ 000$ réis por mês pedidos pelo Fluminense e pelo Flamengo, no ano de 1919. (MALAIA, 2008, p. 145).

Assim sendo, a mensalidade do Ciclo Suburbano era metade da dos clubes ligados à elite carioca, mas bem mais alta (por vezes, o quíntuplo) do que a de outras sociedades suburbanas. Além de tudo, há que se ter em conta o custo de

\footnotetext{
${ }^{15}$ Essa visão persistia desde os primórdios da organização do campo esportivo no Brasil, a noção de Utile Dulce. Para mais informações, ver: MELO, Victor Andrade de. Antes do club: as primeiras experiências esportivas na capital do império (1825-1851). Projeto História, São Paulo, v. 49, p. 140, 2014. Para um debate sobre tais ideias no país dos anos 1920 e 1930, ver: LINHALES, Meily Assbú. A escola e o esporte: uma história de práticas culturais. São Paulo: Editora Cortez, 2009. ${ }^{16}$ Ver: CASA Ideal. A Manhã, p. 6, 23 jun. 1926.
} 
uma bicicleta, um produto financeiramente não acessivel para todos ${ }^{17}$. Logo, àquela altura, possivelmente o acesso à agremiação de Madureira estava mais ajustado aos orçamentos mensais de um estrato social que tinha poder aquisitivo maior do que os frequentadores de clubes populares.

Provavelmente, em função desse perfil, bem como da experiência anterior de alguns associados com o ciclismo, rapidamente se estruturou o Ciclo Suburbano. Logo em janeiro de 1926, promoveu seu primeiro festival, contando com boa participação de esportistas de outros clubes, inclusive alguns já renomados por seus desempenhos atléticos. As quatro provas de diversas distâncias tiveram largada e chegada no Largo do Campinho (O GRANDE..., p. 6, 1926). A boa repercussão do evento foi um estímulo para os jovens envolvidos com a agremiação ${ }^{18}$.

Em julho, outra competição com seis páreos de diferentes distâncias foi promovida pelo Ciclo Suburbano, dessa vez no Jardim Zoológico, localizado em Vila Isabel - desde o final do século XIX um tradicional espaço de organização de eventos esportivos, inclusive provas de ciclismo (CICLISMO - Ciclo Suburbano Clube, p. 7, 1926). Perceba-se que a agremiação não realizou o evento na região de Madureira, e sim num local em que parecia querer se apresentar para toda a sociedade ciclista do Rio de Janeiro.

No mesmo ano de fundação, os associados já estavam também disputando provas como a Corrida Inter-Clubes, organizada pelo Clube Internacional de Ciclistas (CICLISMO - resultado... da Corrida Inter-Clubes, p. 7, 1926) ${ }^{19}$. Vale destacar que, em competição anterior, essa mais antiga agremiação utilizou o Largo do Campinho como local de chegada e largada. A região de Madureira começava a ser reconhecida como referência para os envolvidos com o ciclismo, assim se mantendo mesmo quando, na primeira metade dos anos

\footnotetext{
7 Num anúncio de 1925, percebemos que uma bicicleta custava em torno de 400\$000, quase o preço de uma geladeira (500\$000) (O Jornal, 15 mar. 1925, p. 17). Num reclame de 1934, encontramos um valor de 350\$000, enquanto um corte de seda custava $100 \$ 000$ (O Jornal, 11 nov. 1934, p. 1). Obviamente, temos que considerar que havia muitos modelos de bicicleta, bem como a possibilidade de adquirir o produto de segunda mão.

Ver, por exemplo: O BRILHANTISMO alcançado pelo Ciclo Suburbano Clube em seu festival. Correio da Manhã, p. 6, 12 jan. 1926.

Os associados também tomaram parte em competições de atletismo, como na Prova Pedestre Anual de 60 Quilômetros, promovida pelo Centro Excursionista Brasileiro (EXCURSIONISMO, p. 7, 1926)
} 
1930, o Campo de São Cristóvão se tornou o principal espaço de promoção de eventos (mais utilizado para páreos de velocidade).

Havia um motivo para tal, curiosamente o mesmo que impulsionara os primeiros momentos de urbanização da região. Provas de maior distância usavam estradas da cidade e Madureira seguia sendo o entroncamento de vários caminhos. Se a prova partia do Centro e era de meia distância, chegava no bairro. Se era de longa, passava por ele. Além disso, como os subúrbios ainda não eram intensamente habitados, havia mais facilidade para a organização dos trajetos. Com a fundação do Ciclo Suburbano, tornou-se mais acessível utilizar o local para a promoção de competições, o que agradava a diretoria pelo protagonismo que se concedia à agremiação.

Vale citar que, em muitas ocasiões, o percurso das provas cruzava os subúrbios, bairros como Realengo, Campo Grande e Santa Cruz. Da mesma forma, piqueniques eram promovidos em Jacarepaguá, bem como circuitos organizados para Irajá. Curiosamente, o ciclismo recriava trajetos que nos séculos XVIII e XIX foram trilhados por tropeiros ${ }^{20}$. Não surpreende que em muitos desses bairros tenham sido criados clubes de ciclismo. Juntamente com o futebol, o esporte do pedal parece ter sido, naquele momento, por suas características, o que mais percorreu a cidade de ponta a ponta, criando uma certa capilaridade e estímulo para a prática.

A bicicleta ainda era um produto caro, importado, mas já mais barato do que fora no século XIX, quando era totalmente importada ${ }^{21}$. Na primeira metade do XX, era montada no Brasil e a indústria nacional produzia algumas peças. De fato, apenas em 1948, surgiram as primeiras fabricadas integralmente no país. Tornara-se uma aquisição possível para grupos de estrato médio, uma indicação da própria heterogeneidade da população de Madureira ${ }^{22}$.

\footnotetext{
2 Para exemplificar, o percurso de uma das principais provas, o Circuito da Cidade do Rio de Janeiro, era o seguinte: Centro, Zona da Leopoldina pela Avenida Brasil até Bonsucesso, de lá até Campinho passando por Cascadura e Madureira, seguia em direção a Jacarepaguá pelo Valqueire, posteriormente ia em direção à Barra da Tijuca, São Conrado, Zona Sul até retornar ao Centro. Ver: PRÊMIO de largada: cem mil cruzeiros. Diário da Noite, 11 dez. 1951, p. 24.

1 Sobre o alto valor das bicicletas no século XIX, ver: SCHETINO, André Maia. Pedalando na modernidade: a bicicleta e o ciclismo no Rio de Janeiro e Paris na transição dos séculos XIX e XX. Rio de Janeiro: Apicuri, 2009.

22 Sobre a redução do preço das bicicletas, ver: LESSA, Priscila Requião; MORAES E SILVA, Marcelo.
} 
De toda forma, com os competidores percorrendo muitos bairros da cidade, inclusive os mais afastados do centro, o ciclismo acabou muito apreciado23. Não parece estar de todo equivocado um cronista: "todas as camadas, desde o mais longínquo subúrbio à aristocracia de Copacabana, se interessavam vivamente pelo desenrolar da prova" (A IMPORTANTE..., p. 16, 1933 $)^{24}$.

Já no seu primeiro ano de funcionamento, associados do Ciclo Suburbano tiveram destaque em algumas provas, inclusive uma das mais célebres do ciclismo carioca, os 230 quilômetros da Rio de Janeiro-Petrópolis-Juiz de Fora. Somente sete concorrentes cumpriram o percurso, sendo quatro do clube de Madureira, entre os quais os 1ํ e 20 lugares: José Coelho Mendes, que corria com o pseudônimo de Harley e se tornaria um dos ciclistas mais exaltados nos periódicos da cidade, e Manuel Coelho Mendes. Durante anos, ecoou essa conquista; para Arthur Ferreira, um feito inigualável que enaltecia o clube (RÁPIDAS..., P. 4, 1926).

Nessa prova, surgiu um problema com um dos diretores do Cycle Club, por ele não ter pago aos competidores de Madureira, como prometido, as hospedagens e passagens de retorno à capital nacional (CICLISMO, p. 17, 1926). Tratou-se de um estranhamento entre uma recém-criada agremiação e outra mais consolidada, que possuía um corpo de associados com padrão socioeconômico mais elevado. Na época, o Ciclo Suburbano e o Velo Esportivo de Ramos ${ }^{25}$, ambos do subúrbio, eram os representantes mais novos, enquanto

\footnotetext{
O ciclismo de estrada e a construção de uma cultura nacionalista: um olhar sobre o Tour de France. Movimento, Porto Alegre, v. 23, n. 1, p. 407-418, mar. 2017.

3 Nos países europeus, os circuitos de rua foram importantes estratégias de divulgação do ciclismo, com destaque para o Tour de France, realizado desde 1903. Para mais informações, ver: WEBER, Eugen. França fin de siecle. São Paulo: Companhia das Letras, 1988 e LESSA, Priscila Requião; MORAES E SILVA, Marcelo. O ciclismo de estrada e a construção de uma cultura nacionalista: um olhar sobre o Tour de France. Movimento, Porto Alegre, v. 23, n. 1, p. 407-418, mar. 2017.

${ }^{24}$ Segundo o verbete do CPDOC/FGV, entre 1931 e 1940: "Nas mãos da Estrada de Ferro São PauloRio Grande, A Noite iniciou uma fase de recuperação e de expansão. Uma vez adotada uma linha política comedida e afastadas as campanhas de agressões pessoais, o jornal começou a dar mostras de revitalização, equilibrando-se totalmente até o final da década de 1930". Disponivel em: <https://www.fgv.br/cpdoc/acervo/dicionarios/verbete-tematico/noite-a>. Acesso em: 27 fev. 2020.

${ }^{5}$ A sociedade ciclística de Ramos foi fundada também em 1926, poucos meses depois do Ciclo Suburbano.
} 
Faces da modernidade: a experiência do Ciclo Suburbano Clube (Madureira/Rio de Janeiro - décadas de 1920-1960)

Victor Andrade de Melo, Nei Jorge dos Santos Junior

o Cycle Club e o Clube Internacional de Ciclistas eram mais antigos, possuindo sedes na região central.

Havia só esses quatro clubes de ciclismo. Na opinião de um cronista, faltava um estádio adequado, como já havia em São Paulo ${ }^{26}$, e uma federação para melhor organizar e articular as iniciativas. Assim sendo, as provas de rua eram importantes para a difusão do esporte, mesmo que as atividades de algumas agremiações, a seus olhos, parecessem mais modestas, como sugere ser o caso do Ciclo Suburbano (CICLISMO, p. 8, 1926b) ${ }^{27}$.

Nos seus primeiros anos, "modesto" e "simpático" foram adjetivos usualmente utilizados para definir o clube de Madureira, indícios de que era considerado como de um nível socioeconômico mais baixo. Os associados compunham uma elite reconhecida no bairro, mas não necessariamente na cidade. Era o que Lima Barreto chamava de "aristocracia suburbana”, sugerindo que a heterogeneidade dos subúrbios era mais ampla do que supunha o discurso da imprensa e autoridades políticas da época (SANTOS JUNIOR, 2017). Esse grupo tinha destaque quando se contrastava com os moradores da zona suburbana, mas aos olhos da classe média e alta do Centro ou da Zona Sul não fazia muita diferença.

Em setembro de 1926, já tendo Cantidio Costa como presidente, o Ciclo Suburbano deu mais um passo importante na sua consolidação, especificamente no que tange à visibilidade de suas ações: "A Rua: Semanário Ilustrado" foi escolhido como seu órgão oficial (CICLO Suburbano..., p. 4, 1926b)28. Os informes de diretoria passariam a ter maior divulgação e eficácia na comunicação ${ }^{29}$. Esse

\footnotetext{
Desde o século XIX, em São Paulo, o Velódromo Paulistano foi de grande importância no desenvolvimento do ciclismo e de outros esportes. Para mais informações, ver: GAMBETA, Wilson. A bola rolou: o velódromo paulista e os espetáculos de futebol. São Paulo: Editora Sesi, 2015

${ }^{27}$ Segundo o verbete do CPDOC/FGV, o Correio da Manhã foi um "Jornal carioca diário e matutino fundado em 15 de junho de 1901, por Edmundo Bittencourt e extinto em 8 de julho de 1974. Foi durante grande parte de sua existência um dos principais órgãos da imprensa brasileira, tendo se sempre destacado como um 'jornal de opinião'”. Demonstrou grande adesão aos tenentistas e governo vargas. Disponível em: <https://www.fgv.br/cpdoc/acervo/dicionarios/verbetetematico/correio-da-manha>. Acesso em: 27 fev. 2020

${ }^{28}$ A Rua era órgão oficial de muitas agremiações do subúrbio (ver A RUA, 25 out. 1927, p. 4).

${ }^{29} \mathrm{Na}$ verdade, como era usual, mais de uma vez foram organizadas competições em homenagem à imprensa, tida como importante no que tange à divulgação das atividades e de representações positivas sobre a modalidade. Em evento promovido em 1o de maio de 1927, os oito páreos foram nominados com títulos de periódicos do Rio de Janeiro (CICLISMO, p. 10, 1927b).
} 
foi um aspecto constante na trajetória da modalidade: a participação da imprensa na divulgação e mesmo promoção de iniciativas dos clubes e ligas. Essas ganhavam com a maior visibilidade de suas ações, os periódicos encontravam um bom assunto para atrair compradores. Mais ainda, no tocante às agremiações do subúrbio, procuravam aumentar sua vendagem numa área em que crescia a população.

Em função dessa relação próxima com a imprensa, a estruturação da agremiação tornou-se mais aparente, inclusive as constantes tensões internas e polêmicas, que iam desde a postura política de alguns diretores até a questão de aquisição de uma sede própria ${ }^{30}$. Os enfrentamentos parecem ter se dado em torno de dois grupos, o liderado por Cantidio da Costa e, outro, por Arthur Ferreira.

Percebem-se também as articulações da diretoria com os mais diversos grupos locais. Em 1927, muitas competições do Ciclo Suburbano passaram a ser realizadas no estádio da Companhia de Carros de Combate (Vila Militar). Quem comandava essa unidade militar era Newton Cavalcante, um dos líderes dos movimentos de valorização da educação física, origens da Escola de Educação Física do Exército, que se tornaria uma instituição de grande relevância nacional (FERREIRA NETO, 1999). Trata-se de mais um indício das intencionalidades educacionais que cercavam as iniciativas da sociedade de Madureira.

Na organização dos eventos, além desse apoio frequente do Exército, a diretoria usualmente contava com auxílios dos comerciantes. A premiação (troféus e medalhas), em muitas ocasiões, foi uma oferta de casas localizadas no bairro ou na região central que, como retribuição, nominavam os páreos, uma propaganda e uma estratégia para difundir uma boa imagem (CICLISMO, p. 21, 1927c) $)^{31}$.

\footnotetext{
30 Ver, por exemplo: A OposiçẨo do Ciclo Suburbano Club está gozando. A Rua, p. 4, 3 dez. 1926; AS IMPORTANTES lutas romanas no Ciclo Suburbano Clube. A Rua, p. 4, 26 jul. 1927; OH! Que noite! A Rua, p. 3, 12 jul. 1927.

Nessa prova referenciada, os páreos foram denominados: Casa Colombo Gamberini, especializada em automóveis; Casa Pavageau, dedicada ao comércio de bicicletas; Casa Cruz, uma das mais tradicionais papelarias da cidade, entre outras.
} 
Devemos lembrar que, em boa parte das iniciativas de ciclismo, não se cobrava ingressos do público. Da mesma forma, não havia apostas, alternativa que, no passado, ajudava os clubes esportivos a angariar recursos (MELO, 2001). O discurso moral que cercava o esporte, naquele momento, não permitia mais a venda de poules (com exceção do turfe, que sempre manteve a prática). As agremiações, portanto, se tornaram mais dependentes de auxílios para promover seus eventos. Mesmo enfrentando limitações financeiras, o Ciclo Suburbano tornou-se presença constante nas iniciativas do ciclismo, não somente inscrevendo muitos competidores como também participando como auxiliar ou principal responsável na organização de provas. Além disso, seguiu envolvido ativamente nas ações de estruturação da modalidade na cidade, dentre as quais, a criação da Federação Carioca de Ciclismo e Motociclismo (1931) (CICLISMO, p. 9, 1931).

As competições promovidas pelo clube eram sempre enaltecidas pela imprensa, repercutindo o que se pensava nos meios ciclísticos. Em função dessa expertise, no decorrer do tempo tornou-se responsável por organizar muitas das mais importantes provas da modalidade, inclusive o Circuito da Cidade do Rio de Janeiro, considerada uma das mais prestigiosas do Brasil. Quando isso ocorria, seu nome era veiculado ainda mais constantemente nos periódicos, sempre com referências elogiosas ${ }^{32}$. Tratava-se de uma imagem positiva para uma região que vivia cercada de estigmas usuais que cercavam os subúrbios.

Com uma trajetória de bons resultados - nas disputas e na organização de eventos - o Ciclo passou mesmo a atrair ciclistas de outras agremiações. Em 1927, se comemorou que tinha ingressado no clube o "invencível campeão do pedal, Arlindo Teixeira da Silva, cognominado 'terror dos campeões”" (VALIOSA..., p. 5, 1927). Uma vez mais, a agremiação do subúrbio se apresentava como liderança e protagonista, não como coadjuvante daquilo que ocorria no Centro da cidade.

\footnotetext{
32 Ver, por exemplo: O CICLO Suburbano patrocinará o XII Circuito da Cidade do Rio de Janeiro. O Jornal, p. 16, 3 dez. 1944
} 
Essa repercussão pública agradava aos associados e dirigentes da agremiação, ciosos de que as experiências do bairro pudessem ser valorizadas e consideradas como expressão de que no subúrbio havia iniciativas de adesão a parâmetros de modernidade. Por ocasião de uma posse de diretoria, assim comentou um cronista sobre a "brilhante instituição que de há muito nos vem proporcionando êxito" (CICLISMO, p. 4, 1927d): "Todos os sportmen conhecem bem o vitorioso clube suburbano, portanto, dispensável nos é, tecermos quaisquer elogios a essa briosa sociedade de ciclismo, única talvez que tem sabido cumprir com galhardia o seu programa”.

Perceba-se que o jornalista - há que se ter em conta que se tratava do órgão oficial de imprensa do Ciclo Suburbano - o colocava entre os melhores do Rio de Janeiro. Como já citamos, trata-se de mais um exemplo de como a imprensa e as associações de ciclismo dialogaram no processo de divulgação da modalidade. De toda forma, era positiva a imagem veiculada. Em outra ocasião, se comentou o mau comportamento de um ciclista do Cycle Club. Em contrapartida, a postura da direção da agremiação de Madureira foi tida como “muitos milhões de vezes superior" (CICLISMO, p. 3, 1927e). Nessa representação, o povo do subúrbio não se tratava de gente sem educação, como se representava em alguns estigmas. Era educado, mais até do que alguns das regiões central e sul, um olhar que interessava às lideranças do bairro.

No seu processo de consolidação, nos anos 1930, uma nova fase do Ciclo Suburbano iria se delinear, marcada por uma diversificação de seu quadro de associados. É do que trataremos a seguir.

\section{3-1944 - A caminho do auge: um clube em transição}

A partir de 1933, presidido por Luiz Simões Villas-Boas (figura 4), também ciclista, o clube se tornou ainda mais renomado na cidade, num momento em que houve grande expansão do esporte do pedal. Valem algumas palavras sobre esse personagem. Atentos às questões técnicas da fotografia e formas de embranquecimento a partir delas usuais nas representações correntes desde o 
século $X I X^{33}$, talvez seja possível considerar que era negro o dirigente do Ciclo Suburbano.

Figura 4: Luiz Simões Villas-Boas.



Fonte: Jornal do Brasil, p. 22, 1934a.

A propósito, no clube havia também o ciclista José Duarte, sobre quem os jornais se referiam como "coloured", no mínimo um indício de que poucos eram os negros participantes das competições ciclísticas. As imagens a seguir (figuras 5 e 6), publicadas com destaque em um importante periódico esportivo, mostram como havia negros nas equipes do Ciclo Suburbano, uma expressão de um bairro que tinha conflitos socioeconômicos, mas também muitos pontos de interface. Mais do que tudo, é um indicador da peculiar formação societária da agremiação de Madureira, que passava por mudanças, tornando-se mais aberta a diferentes grupos sociais.

\footnotetext{
3 Para um debate correlato ao tema, ver: SOUZA, Vanessa Raquel Lambert de. O vestuário do negro na fotografia e na pintura: Brasil, 1850-1890. 2007. Dissertação (Mestrado em Artes) Universidade Estadual Paulista, São Paulo, 2007.
} 
Figura 5: Equipe do Ciclo Suburbano.



Fonte: Sport llustrado, p. 28, 1939.

Figura 6: Equipe do Ciclo Suburbano.



Fonte: Sport llustrado, p. 28, 1938. 
Vejamos as fotografias de dois ciclistas (figuras 7 e 8) para enfatizar nossa argumentação de que o Ciclo Suburbano possuía associados de diferentes grupos sociais.

Figura 7: João de Castilho

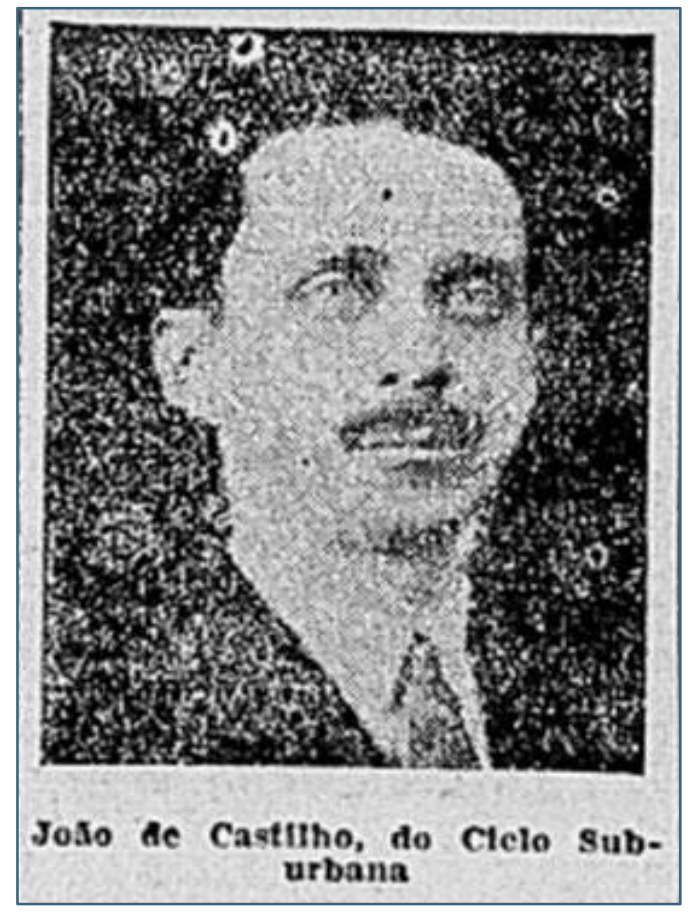

Fonte: Jornal do Brasil, p. 24, 1934b.

Figura 8: Wilson Ferreira de Araújo



Fonte: Jornal do Brasil, p. 25, 1934c. 
Destacamos duas dimensões que nos parecem importantes. Uma delas é o fato de que foram publicadas, em diversas ocasiões, fotos de ciclistas do Ciclo Suburbano. Mesmo que fossem inseridas de forma esparsa nas páginas esportivas, consideramos um indício de que havia algum grau de consideração com a agremiação. A segunda é o fato de que nas imagens das outras sociedades ciclísticas não apareciam tantos atletas de pele negra. Adotando-se os mesmos critérios e ressalvas já feitas no caso de Luiz Simões, aplicáveis também às fotos anteriores, podemos sugerir que era negro outro importante ciclista do Ciclo Suburbano: Thomaz Gomes Figueiredo (figura 9).

Figura 9: Thomaz Gomes de Figueiredo



Fonte: Jornal do Brasil, p. 24, 1934c.

Ele, involuntariamente, em 1934, esteve envolvido em uma discórdia da agremiação de Madureira com a Federação Carioca de Ciclismo e Motociclismo. O motivo foi a desclassificação do atleta do Circuito da Cidade do Rio de Janeiro daquele ano. A diretoria do Ciclo Suburbano não se conformou com tal decisão, mesmo tendo se sagrado vencedor outro de seus ciclistas, Joaquim Peixoto. Como recorreu à prefeitura, os dirigentes da entidade representativa suspenderam o clube por seis meses das competições (CICLISMO, p. 12, 1934). 
A diretoria, então, decidiu por se desligar da Federação. O momento foi marcado, de fato, por uma atitude mais protagonista do Ciclo Suburbano. Aparentemente, a diretoria não se conformava mais em ser coadjuvante. Mobilizando suas conquistas e trajetória, passou a se apresentar como uma liderança da modalidade. Na verdade, conforme surgiram novos clubes, emergiram algumas tensões no âmbito do ciclismo fluminense, o que levou à criação de outra entidade representativa, a Federação Metropolitana de Ciclismo, filiada à Confederação Brasileira de Desportos. Esta, de imediato, convidou o Ciclo Suburbano para se juntar as suas atividades (UM NOBRE..., p. 17, 1934).

Efetivamente, a agremiação de Madureira, nas palavras de um cronista, "incontestavelmente uma das grandes forças do ciclismo em nossa bela


atividades da Federação Metropolitana, especialmente numa espécie de "volta pelo Rio de Janeiro", cerca de 200 km distribuídos em diversos bairros da capital, inclusive em muitos do subúrbio. Como exemplificamos antes, eram trajetos que percorriam várias regiões da cidade. Tal envolvimento foi bastante saudado no Jornal do Brasil, um dos promotores do evento. Uma vez mais, vemos a relação com a imprensa na definição dos caminhos da modalidade. Nesse caso, o periódico desejava atrair uma agremiação que já gozava de reputação.

O clube foi ainda mais exaltado por ter sido o que teve maior número de atletas que terminou o percurso (AS GRANDES..., p. 24, 1934). Ainda assim, e a despeito de já, há tantos anos, estar prestando serviços ao desenvolvimento do ciclismo no Rio de Janeiro, as representações acerca do Ciclo Suburbano expressavam algo da estratificação social da cidade. Numa matéria, percebemse as diferenças na comparação com o Velo Esportivo Helênico, que possuía sede em Ipanema.

\footnotetext{
${ }^{34}$ A essa altura, o Jornal do Brasil, passando por um período de dificuldades financeiras, investiu mais nos classificados do que no seu antigo famoso caráter de crítica aos fatos políticos e cotidianos. Ainda assim, procurou se posicionar de forma moderada em relação a diversas ocorrências nacionais e da cidade, vislumbrando não perder o público popular que conseguira atrair nas décadas anteriores (verbete Jornal do Brasil, CPDOC/FGV, disponível em: <https://www.fgv.br/cpdoc/acervo/dicionarios/verbete-tematico/jornal-do-brasil>. Acesso em: 26 fev. 2020).
} 
A agremiação de Madureira, "cujo passado glorioso muito honra o ciclismo nacional" (O PROGRESSO..., p. 22, 1934), foi apresentada como "um clube modesto, não resta dúvida, mas valoroso e leal”, destacando-se que a “apresentação da rapaziada do Suburbano sempre foi digna de nota”. Já o Helênico foi referido como "o mais próspero que possuímos", "pronto a tudo fazer pela prosperidade do esporte do pedal".

De toda forma, foi muito celebrada pelo Jornal do Brasil a filiação da sociedade esportiva suburbana à Federação Metropolitana. Fez-se questão, inclusive, em meio a muitos elogios à tenacidade dos seus associados, de se registrar que "Infelizmente, o Ciclo Suburbano, devido a sua lealdade esportiva, tem sido vítima de injustiças várias" (O PROGRESSO..., p. 22, 1934), uma referência aos conflitos com a outra liga.

Como antes, a agremiação tornou-se uma das mais ativas seja na inscrição de competidores, seja promovendo competições. Seus feitos continuaram a ser elogiados, usualmente se citando seu bairro de origem: Madureira. Imagens de suas equipes e atletas constantemente foram publicadas nos jornais e mesmo nas revistas mais prestigiosas da cidade, como a Revista da Semana (figura 10) ${ }^{35}$.

Figura 10: Comemoração do 9 aniversário do Ciclo Suburbano.

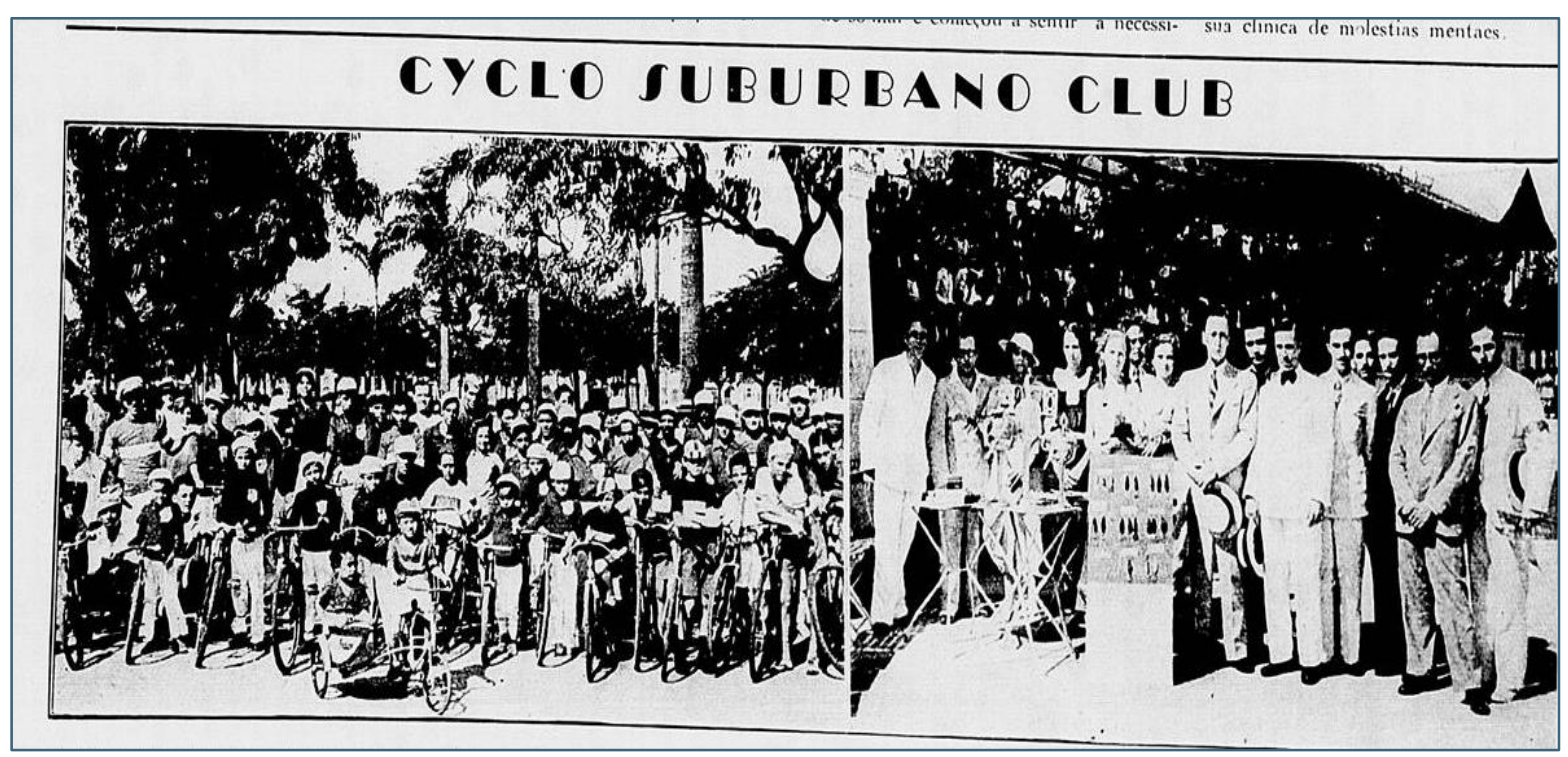

Revista da Semana, p. 32, 19 jan. 1935. 
Em 1935, o Ciclo Suburbano teve participação ativa na chamada "pacificação do ciclismo do Rio de Janeiro", quando as duas federações existentes se fundiram dando origem à Liga Carioca de Ciclismo e Motociclismo, ligada à Federação Ciclística Brasileira e à União Ciclística Internacional (PACIFICADO..., p. 20, 1935). Na verdade, o envolvimento da agremiação de Madureira, em função dos desgastes anteriores, acabou sendo um ponto fulcral. Os representantes do clube, na reunião que decidiu a unificação, chegaram a divergir; Luiz Simões concordando e Coelho Mendes votando em contrário em razão de os sócios não terem sido consultados (INSTALADA..., p. 3, 1935). Ao fim, sacramentou-se a participação do Ciclo Suburbano na nova entidade.

Nos jornais, transparecia muito respeito pela trajetória e realização dos ciclistas de Madureira. Sobre o festival que promoveu para comemorar seu 9o aniversário, comentou um cronista: "Composto como é de uma plêiade de dedicados cultores do esporte do pedal, o valoroso Ciclo Suburbano Clube vai dar ainda uma vez mais a demonstração de sua pujança e do muito que tem feito por este ramo do esporte" (A ABERTURA..., p. 25, 1935). Posteriormente, não faltaram elogios da imprensa a todos aspectos da organização, bem como dos resultados.

Em 1938, o Ciclo Suburbano foi o vencedor do Campeonato Carioca. Durante anos, foi a agremiação mais vitoriosa do ciclismo do Rio de Janeiro. Constituía-se mesmo em algo inusitado haver uma sociedade do subúrbio que, mesmo, pelos cronistas, sempre considerada modesta, era respeitada como uma das mais importantes da cidade. Além disso, num momento em que o ciclismo se espraiou para outros bairros da Zona Oeste (como Campo Grande, Realengo e Higienópolis), era reconhecida como a liderança local, a reboque de Madureira estar se configurando como "capital do subúrbio".

Essa foi sempre uma estratégia do Ciclo Suburbano. Participou ativamente de provas em todas as localidades da cidade, dialogando constantemente com agremiações das zonas central e sul, mas sempre valorizou a experiência do subúrbio, no sentido de colaborar com as iniciativas da região. De outro lado, essa atuação também alimentou rivalidades, pois sempre pareceu claro o seu desejo de assumir o protagonismo local. Isso fora acalentado, já na década de 
1920, em eventos nos quais havia provas que contavam somente com a participação do Velo Esportivo de Ramos ${ }^{36}$, ocasiões em que grassava um clima de celebração de uma identidade suburbana, mas também disputas sobre quem seria o protagonista da zona na modalidade. A propósito, as outras agremiações da região carregavam o nome do bairro (Realengo Pedal Clube, União Ciclística de Campo Grande, Pedal Clube Higienópolis), enquanto a de Madureira assumia a vinculação direta com o subúrbio.

Nas notícias de suas atividades, percebe-se as muitas mudanças de sede do Ciclo Suburbano. Em 1936, o clube se instalou na Rua Nicarágua, no bairro da Penha. Dois anos depois, voltou para Madureira, na Rua Agostinho Barbalho. Em 1939, retornou para a Penha, na Rua Circular. Em 1943, de novo em Madureira, na Praça Inácio do Couto. Parecia uma agremiação consolidada, mas o problema da sede se apresentava como um impeditivo para seu maior desenvolvimento. Em 1944, instalou-se finalmente num espaço mais adequado, onde viveria seu auge, bem como seu ocaso. A sede da Rua Capitão Couto Menezes acolheu grandes momentos promovidos pela sociedade ciclística.

\section{4-1968(?) - Do auge ao fim - um clube suburbano}

O auge da atuação do Ciclo Suburbano não foi algo somente tributário de sua trajetória. Depois de décadas lutando contra a estigmatização dos subúrbios e entabulando ações no sentido de apresentar a região como também participante dos ideais de civilização e progresso, nas décadas de 1940-1960, as lideranças locais viram algo de seu esforço reconhecido. Para Fraga e Santos (2015, p. 15):

A composição social dos subúrbios (ocupado majoritariamente por setores populares) não se modificou. Porém, como os setores populares espalharam-se por toda cidade pela disseminação de favelas, minimizou-se, por certo tempo, o contraste social entre subúrbios, centro e zona sul (ABREU, 1987). Esse quadro, aliado a um período de grande prosperidade comercial e industrial de algumas regiões suburbanas, intensificou nessas duas décadas a crença das camadas médias de que, finalmente, a hora e a vez dos subúrbios haviam chegado. (FERNANDEZ, 1996).

\footnotetext{
${ }^{36}$ Ver, por exemplo, um evento organizado nas dependências do estádio da Companhia de Carros de Combate (Vila Militar) (CICLISMO, p. 10, 1927f).
} 
Como eram parcos os investimentos estatais, grande parte do desenvolvimento do subúrbio partiu das próprias lideranças locais, no caso de Madureira, protagonizado pelos comerciantes, que construíram uma imagem de que suas ações iam além do interesse pessoal, tendo em conta o bem público. Por isso, apoiavam diversas iniciativas, inclusive aquelas de benemerência e filantropia (FERNANDEZ, 2005). Pode-se ver claramente essas dimensões na trajetória do Madureira Esporte Clube, já citado na introdução. A participação de comerciantes sempre foi denotada. A construção do estádio da Rua Conselheiro Galvão, inaugurado em 1941, foi em grande parte liderada e financiada por Aniceto Moscoso, que era mesmo o proprietário do terreno. O personagem, que foi durante muitos anos presidente da agremiação, atuava no âmbito comercial (GERSON, 2000, p. 436).

Durante esse período, no que tange ao envolvimento do Ciclo Suburbano com o ciclismo, a princípio não houve grande mudança: o clube continuou sendo um dos protagonistas da modalidade. Percebe-se mesmo é o ampliar de suas funções no bairro, inclusive apoiando uma escola.

Não sabemos exatamente quando foi criada a Escola 10 de Julho, provavelmente na década de 1940 (RIO DE JANEIRO, 1950), bem como quando passou a se relacionar mais amiúde com o Ciclo Suburbano, possivelmente nos anos 1950. Percebe-se que, em 1952, recebeu subsídios do governo municipal (BRASIL, 1952). Era uma instituição educacional privada de ensino infantil que acolhia filhos dos populares e, a partir de certo momento, passou a receber apoio da agremiação de ciclismo.

Em 1950, o Ciclo recebera pela primeira vez subsídios do governo municipal para auxiliar em suas obras assistenciais (BRASIL, 1950, p. 8). Outros mais semelhantes ocorreriam no decorrer da década. Em 1955, identificamos que havia no clube um Centro Social, provavelmente oferecendo alguns serviços à população de Madureira (BRASIL, 1955, p. 18). Trata-se de poucas e esparsas informações, mas é possível inferir que o Ciclo Suburbano tenha ampliado sua atuação comunitária, dedicando-se mais ao desenvolvimento do bairro, prestando assistência a partir de sua rede de contatos e colaboradores. 
Adequara-se mais aos parâmetros que adotara, como citado, um setor das elites de Madureira e do subúrbio.

Da mesma forma, percebe-se que seus salões eram utilizados para reuniões sociais e eventos de outros clubes esportivos que não possuíam uma sede tão ampla ${ }^{37}$. Além disso, passou mais constantemente a organizar reuniões dançantes e bailes de carnaval, festividades muito valorizadas em Madureira ${ }^{38}$.

A propósito, na sede da Capitão Couto Menezes se encontrava, por ocasião das eleições, as urnas da 77a e 78a seções da 13aㅡ Zona Eleitoral (JORNAL do Brasil, p. 7, 1958). De fato, o Ciclo Suburbano participava ativamente dos eventos da sociedade civil de Madureira, tanto nos de caráter social quanto nos de cariz cívico, bem como nas iniciativas esportivas, como uma olimpíada do bairro promovida com apoio do Jornal dos Sports, em 1965 (JORNAL dos Sports, p. 7, 1965).

O destaque que neste artigo damos para a aquisição de uma nova sede pelo Ciclo Suburbano, considerada mais confortável e adequada a seus intuitos, dialoga com as apreensões de Fraga e Santos (2015, p. 17). Para os autores, nos subúrbios, "a construção de belas casas e edifícios e a preocupação com o estilo e a beleza da fachada das residências podem ser entendidas como uma tentativa de reverter ou minimizar a ausência de investimentos públicos em obras de infraestrutura urbana". Vejamos que a sede foi tombada exatamente por seu perfil arquitetônico:

considerando a importância cultural dos imóveis que constituem testemunhos das primeiras construções dos bairros de Madureira e Campinho; considerando a indispensável proteção dos imóveis que fazem parte da história urbana da região onde se situam os bairros de Madureira e Campinho; considerando a necessidade de se adotarem medidas de proteção para preservar importantes marcos da história da ocupação dos bairros da Cidade do Rio de Janeiro. (RIO DE JANEIRO, 2004).

\footnotetext{
${ }^{37}$ Ver, por exemplo, ocasião em que cedeu os salões ao E. C. Travessa, também de Madureira (E. C. TRAVESSA, p. 6, 1957).

${ }^{38}$ Ver, por exemplo: O Jornal, 15 out. 1961, p. 2; DIÁRIO de Notícias, 12 out. 1961, p. 3; BAILES infantis autorizados. A Manhã, 15 fev. 1952, p. 11; e CICLO Suburbano Clube. Correio da Manhã, 26 jan. 1956, p. 10
} 
Para conseguir o novo espaço, a diretoria contou com o apoio de antigos associados e de alguns comerciantes do bairro. De toda forma, ciosa de seguir aperfeiçoando sua sede, em 1962, lançou um programa de sócios-proprietários (DIÁRIO de Notícias, p. 5, 1962). A ideia era não mais precisar deixar a esquina da Rua Capitão Macieira com Rua Capitão Couto Menezes.

De fato, uma das facetas que mais se destaca na trajetória do Ciclo Suburbano é sua longa duração. Em 1951, o anúncio da 18a edição do Circuito do Rio de Janeiro trazia várias ideias de continuidade (O 18 CIRCUITO..., p. 10, 1951). Ressaltava-se que vinha sendo realizado há muitos anos, boa parte das edições organizadas pelo clube de Madureira. Destacava-se que o formato sempre foi muito semelhante: prova realizada em um domingo, com largada no início da tarde, da região central, com percurso percorrendo boa parte da cidade, inclusive os subúrbios. Lembrou-se que era uma das mais importantes competições ciclísticas, testando ao máximo as habilidades dos atletas.

Havia, contudo, um diferencial no que tange aos clubes: nenhum deles disputara o Circuito desde o início, nem participava de competições ciclísticas quando os atletas do Ciclo Suburbano começaram em 1926. A agremiação chegava aos 25 anos e continuava bastante ativa, organizando eventos, participando de praticamente todas as competições (em muitas ocasiões, obtendo bons resultados), atuando de forma protagonista na Federação. Uma vitalidade destacável para uma sociedade que, nos seus anos iniciais, era chamada de modesta.

Por certo, o Ciclo foi se adaptando ao tempo. No que se refere ao aspecto esportivo, o ciclismo mudou muito, tendo a agremiação se mantido atenta. No decorrer dos anos, incorporou a prática de novos esportes por demandas dos sócios: tênis de mesa, judô, jiu-jitsu, boxe, voleibol, motociclismo. Chegou até mesmo a formar uma equipe de futebol que estabeleceu uma rivalidade com o Nacional Futebol Clube, sediado no Campinho, e com o Veteranos F. C., de Madureira (VETERANOS, p. 2, 1959).

Em 1964, todavia, surgiram os primeiros sinais de problemas no Ciclo Suburbano. Numa breve entrevista, um certo Guaraci Botelho sugeriu que o clube entraria em uma nova fase pois "vários fatores" dificultavam sua expansão 
(SOCIAL Ciclo..., p. 7, 1964). Um dos sintomas foi sua ausência em certas competições, algo que se tornou mais usual em 1965. A agremiação também não honrou o compromisso de organizar algumas provas, algo inusitado na sua trajetória (ENCERRAMENTO..., p. 55, 1968). Ainda assim, em 1968, foi protagonista do motociclismo fluminense, organizando provas no Autódromo de Jacarepaguá, obtendo mesmo bons resultados (MANUEL..., p. 7, 1968).

O fato é que, depois de 1968, não encontramos nos jornais mais notícias sobre o Ciclo Suburbano. É possível que ainda tenha ficado algum tempo ativo sem promover qualquer evento, como é comum com clubes que estão prestes a cerrar suas portas. Ficamos sem saber quando e o que houve para que chegasse ao fim. Teria havido alguma dificuldade de renovação de sócios? Algum conflito interno ou no bairro? Queda de interesse pela modalidade? Mudança de perfil do local a interferir no seu funcionamento? Não conseguimos indícios para responder tais questões.

De toda forma, ainda que nos dias de hoje seja pouco lembrado, deixaram marcas os mais de 40 anos de atuação do Ciclo Suburbano, um clube que colocou Madureira no mapa da cidade para além das importantes contribuições do bairro para o comércio e para o carnaval.

\section{Conclusão}

O Ciclo Suburbano foi um importante espaço de sociabilidade do bairro de Madureira. Num primeiro momento, envolveu mais setores da elite local, especialmente ligados ao comércio. Claramente, buscava se estabelecer como uma alternativa para esse grupo que pretendia adotar parâmetros de vida mais adequados à ideia de civilização e progresso à moda do que se propugnava nas zonas privilegiadas do Rio de Janeiro. Apresentava, assim, um contraponto, no mínimo uma alternativa, aos divertimentos mais frequentados pelas camadas populares. Na mesma medida, oferecia à cidade uma visão menos estigmatizada do subúrbio.

O segundo momento de sua trajetória foi marcado pela consolidação de sua atuação na cidade e no bairro, tornando-se ainda mais uma propaganda 
positiva de Madureira. Nesse instante, já se percebem os novos arranjos sociais que havia na região, tanto o fato de que certos populares tinham ascendido socialmente, quanto o fato de que houve uma aproximação entre os diferentes estratos, um processo claro de circularidade cultural que acabou por forjar uma identidade local fruto de uma certa articulação entre as ideias de modernidade e tradição. Atento a esse movimento, equilibrando-se entre as elites locais, as elites da cidade, os distintos grupos da região e as agremiações do subúrbio, o Ciclo Suburbano se encaminhou para sua fase áurea.

Pari passu com um momento em que houve uma certa valorização dos subúrbios, o Ciclo Suburbano chegou no auge de sua atuação. No ciclismo, tornara-se presença constante e respeitada, colocando Madureira no mapa do esporte carioca. Suas atividades se ampliaram para envolver maior número e mais amplo perfil de interessados. Nesse momento, quando se instalou numa sede mais adequada, passou a ser uma referência social, cívica e esportiva de Madureira, acolhendo os mais distintos tipos de reuniões e eventos - desde bailes de carnaval até a realização de eleições. O apoio a uma escola e a criação de um centro social são expressões de que estava sintonizado com as necessidades e o processo de desenvolvimento do bairro.

Seu fim, permanece, para nós, um mistério. As fontes consultadas praticamente as únicas que há sobre o clube, não nos oferecem mais informações para entendermos por que o Ciclo Suburbano cerrou suas portas. De toda forma, vale destacar o quanto a experiência do Ciclo Suburbano ajuda a contrastar visões restritas, monolíticas e estigmatizadas do subúrbio. Ela é uma expressão da heterogeneidade social, da diversidade de ocorrências e do papel protagonista das lideranças locais.

Tal compreensão induz-nos a lançar um olhar mais amplo e matizado sobre a história do Rio de Janeiro e sobre a história do esporte, que não devem ser interpretadas apenas a partir do que ocorreu nas zonas mais privilegiadas socioeconomicamente. Assim sendo, este estudo é também uma contribuição para a história do subúrbio carioca. 


\section{Referências}

A ABERTURA da temporada ciclística carioca de 1935. Jornal do Brasil, p. 25, 9 jan. 1935.

A IMPORTANTE tarde ciclística de ontem. A Noite, p. 16, 16 nov. 1933.

ABREU, Maurício. A evolução urbana do Rio de Janeiro. Rio de Janeiro:

IPLANRIO, 1987.

AS GRANDES provas cariocas de ciclismo. Jornal do Brasil, p. 24, 23 mai. 1934.

BRASIL. Estatutos do Ciclo Suburbano Clube. Diário Oficial da União, p. 3, 10 set. 1949.

BRASIL. Diário Oficial da União, 13 dez. 1950, p. 8.

BRASIL. Diário Oficial da União, p. 8-11, 8 dez. 1952.

BRASIL. Diário Oficial da União, 6 jan. 1955, p. 18.

BRITO, João Felipe Pereira. A construção estratégica do bairro de Madureira na Cidade Olímpica: novas espacialidade, temporalidades e conflitos no Rio de Janeiro de megaeventos. Tese (Doutorado em Sociologia). Rio de Janeiro: UFRJ, 2016.

CANCLINI, Néstor García. Culturas híbridas: estratégias para entrar e sair da modernidade. São Paulo: Edusp, 1997.

CICLISMO. O Brasil, Rio de Janeiro, p. 8, 21 out. 1925.

CICLISMO. O Paiz, p. 17, 4 abr. 1926.

CICLISMO. Correio da Manhã, p. 8, 31 jul. 1926b.

CICLISMO. A Rua, p. 4, 26 jul. 1927.

CICLISMO. O Imparcial, p. 10, 20 abr. $1927 b$.

CICLISMO. Correio da Manhã, p. 21, 6 fev. 1927c.

CICLISMO. A Rua, p. 4, 20 jan. 1927d.

CICLISMO. A Rua, p. 3, 8 fev. 1927e. 
CICLISMO. O Imparcial, p. 10, 4 fev. $1927 f$.

CICLISMO. Diário de Notícias, p. 9, 29 set. 1931.

CICLISMO. Correio da Manhã, p. 12, 20 mar. 1934.

CICLISMO - Ciclo Suburbano Clube. Gazeta de Notícias, p. 7, 3 jul. 1926.

CICLISMO - resultado da Corrida Inter-Clubes. Gazeta de Notícias, p. 7, 16 set. 1926.

CICLO Suburbano Clube. A Rua, p. 4, 25 nov. 1926.

CICLO Suburbano Clube. A Rua, p. 4, 10 set. 1926b.

O CICLO Suburbano tomará parte na excursão. Jornal do Brasil, p. 24, 15 mai. 1934.

CRUZ, Aline Torres Dias da. Suburbanização e racismo no Rio de Janeiro: uma leitura de Madureira e Dona Clara no contexto pós-emancipação (1901 - 1920). Dissertação (Mestrado em Planejamento Urbano e Regional). Rio de Janeiro: UFRJ, 2007.

O 18o CIRCUITO Ciclístico do Rio de Janeiro. Diário da Noite, p. 10, 7 dez. 1951.

DIÁRIO de Notícias, p. 5, 17 mai. 1962.

ENCERRAMENTO da temporada carioca. Diário de Notícias, p. 55, 15 dez. 1968.

EXCURSIONISMO. Jornal do Comércio, p. 7,1 out. 1926.

FERNANDES, Nelson da Nobrega. O rapto ideológico da categoria subúrbio. Rio de Janeiro: UFRJ, 1995.

FERNANDES, Nélson da Nóbrega. Escolas de samba: sujeitos celebrantes e objetos celebrados. Rio de Janeiro: Arquivo Geral da Cidade do Rio de Janeiro, 2001.

FERNANDEZ, Annelise Caetano Fraga. Orgulho suburbano: o projeto de dignificação dos subúrbios do Rio de Janeiro na imprensa de bairro, 1948-1957. Cadernos CERU, São Paulo, série 2, n. 16, p. 143-162, 2005.

FERREIRA NETO, A. A pedagogia no exército e na escola: a educação física brasileira (1880-1950). Aracruz: FACHA, 1999. 
FRAGA, Annelise Caetano; SANTOS, Miriam de Oliveira. Madureira, Capital dos Subúrbios (1940-1960): carnaval e comércio na produção de uma comunidade imaginada. Iluminuras, Porto Alegre, v. 16, n. 37, p. 11-31, jan.-jun. 2015.

GERSON, Brasil. A história das ruas do Rio. Rio de Janeiro: Lacerda, 2000.

O GRANDE festival de amanhã do Ciclo Suburbano Clube. A Manhã, p. 6, 9 jan. 1926.

GUIMARAES, Roberta Sampaio; DAVIES, Frank Andrew. Alegorias e deslocamentos do "subúrbio carioca" nos estudos das Ciências Sociais (19702010). Sociologia \& Antropologia, Rio de Janeiro, v. 8, n. 2, p. 457-482, ago. 2018.

INSTALADA a Liga Carioca de Ciclismo. A Noite, p. 3, 25 abr. 1935.

INSTITUTO PEREIRA PASSOS. Dados do Rio - bairros. Rio de Janeiro: Instituto Pereira Passo, 2020. Disponível em: <https://apps.data.rio/armazenzinho/>. Acesso em: $21 \mathrm{fev} .2020$.

JORNAL do Brasil, p. 22, 16 jun. 1934a.

JORNAL do Brasil, p. 25, 22 mai. 1934b.

JORNAL do Brasil, p. 24, 18 mai. 1934C.

JORNAL do Brasil, p. 7, 3 out. 1958.

JORNAL dos Sports, p. 7, 12 jan. 1965.

LEFEBVRE, Henry. A produção do espaço. Trad. Doralice Barros Pereira e Sérgio Martins. 2006 (do original: La production de l'espace. 4e éd. Paris: Éditions Anthropos, 2000).

LUCA, Tânia Regina. História dos, nos e por meio dos periódicos. In: PINSKY, Carla B. (org.). Fontes históricas. São Paulo: Ed. Contexto, 2005. p. 111-153.

MALAIA, João Manuel. O processo de profissionalização do futebol no Rio de Janeiro: dos subúrbios à Zona Sul. A inserção de negros, mestiços e brancos pobres na economia da Capital Federal (1914-1923). Leituras de Economia Política, Campinas, n. 13, p. 125-155, jan.-jul. 2008.

MANUEL vence prova MF. Jornal dos Sports, p. 7, 27 ago. 1968.

MARTINS, Ronaldo Luis. Mercadão de Madureira: caminhos de comércio. Rio de Janeiro: Condomínio do Entreposto Mercado do Rio de Janeiro, 2009. 
MELO, Victor Andrade de. Cidade sportiva: primórdios do esporte no Rio de Janeiro. Rio de Janeiro: Relume Dumará/Faperj, 2001.

MELO, Victor Andrade de. Novas performances públicas: os clubes athleticos e a educação do corpo (Rio de Janeiro, 1884-1889). Cadernos de História da Educação, Uberlândia, 2020.

MELO, Victor Andrade de; FONSECA, Vivian Luiz; PERES, Fabio Faria. Patrimônio esportivo: um tema de investigação. Projeto História, São Paulo, v. 59, p. 261284, abr.-jul. 2017.

MIYASAKA, Cristiane Regina. Os trabalhadores e a cidade: a experiência dos suburbanos cariocas (1890-1920). Tese (Doutorado em História). Campinas: Universidade Estadual de Campinas, 2016.

O PROGRESSO do ciclismo carioca. Jornal do Brasil, p. 22, 9 jun. 1934.

OLIVEIRA, Márcio Piñon de Oliveira; FERNANDES, Nelson da Nóbrega (orgs.). 150 anos de subúrbio carioca. Rio de Janeiro: Lamparina/Faperj/EdUFF, 2010.

O JORNAL, 15 mar. 1925, p. 17.

O JORNAL, 11 nov. 1934, p. 1.

PACIFICADO o ciclismo carioca. Gazeta de Notícias, p. 20, 21 abr. 1935.

RANGEL, Marcelo de Mello; RODRIGUES Rogério Rosa. E a história hoje...Tempo e Argumento, Florianópolis, v. 10, n. 24, p. 4-5, 2018.

RÁPIDAS palavras com o sportman Arthur Ferreira. A Rua, p. 4, 11 nov. 1926.

REVISTA da Semana, p. 32, 19 jan. 1935.

RIBEIRO, Ana Paula Alves. Samba são pés que passam fecundando o chão... Madureira: sociabilidade e conflito em um subúrbio musical. Dissertação (Mestrado em Ciências Sociais). Rio de Janeiro: UERJ, 2003.

RIO DE JANEIRO. Anuário Estatístico do Distrito Federal, ano XIII, 1950, p. 52.

RIO DE JANEIRO. Prefeitura da Cidade do Rio de Janeiro. Decreto no 24560 de 25 de agosto de 2004. Tomba provisoriamente os imóveis que menciona. Disponível em: <https://leismunicipais.com.br/a/rj/r/rio-dejaneiro/decreto/2004/2456/24560/decreto-n-24560-2004-tombaprovisoriamente-os-imoveis-que-menciona>. Acesso em: 13 mar. 2020. 
SANTOS JUNIOR, Nei Jorge. A vida divertida suburbana: representações, identidades e tensões em um arrabalde chamado Bangu (1895-1929). Tese (Doutorado em Estudos do Lazer). Belo Horizonte: UFMG, 2017.

SCHMID, Christian. A teoria da produção do espaço de Henri Lefebvre: em direção a uma dialética tridimensional. GEOUSP - Espaço e Tempo, São Paulo, n. 32, p. 89- 109, 2012.

SILVA, Lucia Helena Pereira da. História do urbanismo do Rio de Janeiro: administração municipal, engenharia e arquitetura dos anos 1920 à Ditadura Vargas. Rio de Janeiro: E-Papers, 2003.

SOCIAL Ciclo Suburbano em nova fase. A Luta Democrática, p. 7, 28 ago. 1964.

SPORT Ilustrado, p. 28, 5 out. 1938.

SPORT Ilustrado, p. 28, 28 set. 1939.

UM NOBRE gesto esportivo da F.M.C. Jornal do Brasil, p. 17, 8 mai. 1934.

VALIOSA aquisição para o Ciclo Suburbano. A Rua, p. 5, 21 abr. 1927.

VETERANOS F. C., de D. Clara, e seu festival amanhã. Diário da Noite, p. 2, 30 mai. 1959, p. 2. 